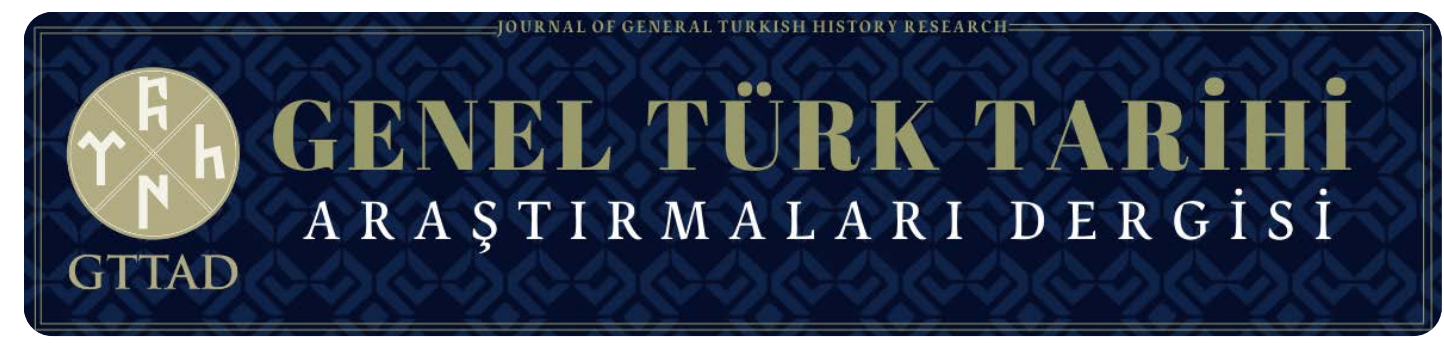

Cilt/Volume 4, Sayı/Issue 7, Ocak/January 2022, ss. 23-42.

Geliş Tarihi-Received Date: 19.12.2021 Kabul Tarihi-Accepted Date: 02.01.2022

\author{
ARAŞTIRMA MAKALESİ - RESEARCH ARTICLE \\ GÖKTÜRK DÖNEMI HAREZM GÖRSEL SANATINDA TÜRK KIMLİĞİ \\ (TOK-KALE OSSUARI ÖRNEĞINDE)
}

(DMLIKA TUKHTAYEVA*

do.53718/gttad.1038625

Öz

Bu makale, Batı Türkistan’ın Harezm bölgesinde bulunan Tok-Kale arkeoloji yerleşiminde ele geçirilen ve üzerine "merhum için yas” sahnesi çizilen bir ossuar, yani ölülerin kemiklerini barındıran kaynaktaştan yapılmış kutuyla ilgilidir. Göktürk Dönemi'ne tarihlenen bu ossuarın benzersizliği, onu süsleyen resmin Harezm geleneği ile Türk-Soğd etkisinin bir kombinasyonunu taşıması gerçeğinde yatmaktadır. Kronolojik olarak, Türklerin sanat geleneklerinin Harezm bölgesine nüfuz etmesinin ve yerel sanatla, örneğin Soğd ile etkileşiminin ilk aşamasının, araştırmacılar tarafından 6 . ve 9. yüzyıllarda belirlendiği tespit edilmiştir. Bu kronoloji, oldukça doğru bir şekilde tespit edilen ve Erken Orta Çağ bozkır kültürüyle ilgili olan sanat ve zanaat nesnelerine dayanmaktadır. Türk unsurlarının daha ayrıntılı bir şekilde incelenmesi ve tanımlanması ile yerel kültürel geleneklerin bazı detaylarının belirlenmesi için arkeologların ve sanat tarihçilerinin hizmetine sunulan çok sayıda arkeolojik eser bulunmaktadır. Bulgular, bazı durumlarda dönemin karakteristik özelliklerini belirlemeye izin verir. Örneğin, estetik özellikler, defin töreninin ve mezar eşyalarının süslenme biçimine büyük ölçüde yansır.

Ossuarlar üzerinde yapılan resimlerin ilk araştırmacılar tarafından Zerdüştlük ile ilişkilendirilmesi özellikle dikkate değerdir. Sovyet Dönemi sanat tarihçileri böyle resimlerin ossuarlar üzerinde yapılmış olması, onları Zerdüştlük ile ilişkilendirilmesine neden olduğunu belirtmişlerdir. Onlar için resimlerle süslenmiş kil ossuarlara kemikleri gömen İran Dağlık Bölgesi Zerdüştlerinin gömme gelenekleri buna bir örnek teşkil etmiştir. Öte yandan, ortodoks Zerdüştlükte ölü için yas tutmanın yasak olduğu bilinmektedir. Bu durum ise, Batı Türkistan bölgesinde Zerdüştlüğün kutsallaştırılmadığını ve muhtemelen çeşitli konar-göçer kültürlerin unsurlarını içeren kendine özgü ritüel özelliklerine sahip olduğunu gösterir. Genel olarak, Tok-Kale resimli ossuarı, Erken Orta Çağ Orta Asya’sında, en azından defin töreni ile ayırt edilen özel bir Zerdüştlük biçiminin varlığına tanıklık eder.

Söz konusu ossuardaki görselin unsurları olan kutsal semboller ve görüntüler, Harezm ahalisinde ruhun bireyselliğini korumaya devam edecek olan öbür dünya hakkında dini inançlarının varlığına tanıklık etmektedir. Kullanılan sembolizm, ressamın sanat eserlerinin içeriğini derin bir anlamla doyurmasını sağlamıştır. Ayrıca, bu ossuarda tasvir edilen karakterlerin Türk kimliğini taşıdığı anlaşılmaktadır. Bu çalışmada, Türklerin dış görünümü hakkında bugüne kadar birikmiş kapsamlı materyalin (görsel, etnografik, antropolojik ve yazılı kanıtların) incelenmesine ve Tok-Kale ossuarındaki karakterlerin saç stilleri ve kostümlerinin analizine dayanarak bilgilere sahip olabiliyoruz. Tarihyazımsal materyalin analizi, Tok-Kale ossuarının Sovyet sanat eleştirmenleri tarafından yetersiz tanımlandığı sonucuna varmayı mümkün kılmaktadır. Mevcut yayınlar, uzun saç modellerine ve örgülere dayalı olarak, karakterlerin cinsiyetine ilişkin bazı asılsız sonuçları ortaya çıkarmıştır. Böylece, Göktürk Dönemi Türk erkeklerinin bir veya birkaç örgüye sahip olmaları tespit edilmekte ve tasvir edilen karakterlerin kostümlerinin analizi, onların cinsiyetlerinin en güvenilir kanıtı olarak ortaya çıkmaktadır. Yas ritüeli ve defin töreninin ossuar üzerinde tasviri, yalnızca belirli bir kültürün taşıyıcısının anlayabileceği bir tür "ikincil modelleme sistemi” olduğu da anlaşılmaktadır. Araştırmacılar ise yalnızca görsel işaretlerin dilini sınırlı derecede açıklayabilmekte ve yorumlayabilmektedir.

Anahtar Kelimeler: Göktürk, Harezm, Ossuar, Zerdüştlük, Giysi, Saç Örgüsü, Mitoloji.

\footnotetext{
* Dr., Özbekistan Milli Arkeoloji Merkezi, ÖZBEKISTAN, E-Posta: artgirl83@list.ru, ORCID ID: 0000-0003-1456-1573
} 


\title{
GÖKTÜRK DÖNEMİ HAREZM GÖRSEL SANATINDA TÜRK KIMLİ̆̆i (TOK-KALE OSSUARI ÖRNEĞİNDE)
}

\section{TURKIC IDENTITY IN THE VISUAL ART OF THE GÖKTÜRK PERIOD KHWAREZM (ON THE EXAMPLE OF THE TOK-KALA OSSUARY)}

\begin{abstract}
The article is about an ossuary, an alabaster box containing the bones of the dead, on which a "mourning for the deceased" scene is depicted. It was found in the archaeological settlement of Tok-Kala in the Khwarezm region of West Turkestan. The uniqueness of this ossuary, dating to the Gokturk Period, lies in the fact that the painting that adorns it bears a combination of Khwarezm tradition and Turkish-Sogdian influence. Chronologically, it has been determined that the first stage of the penetration of the artistic traditions of the Turkic peoples into the Khwarezm region and their interaction with the local art, for example, with the Sogdian, was determined by the researchers as the $6^{\text {th }}$ and $9^{\text {th }}$ centuries $\mathrm{AD}$. This chronology is based on the art and craft objects that have been identified quite accurately and are related to the Early Medieval steppe culture. There are many archaeological artifacts available to archaeologists and art historians to examine and describe the Turkic elements in more detail and to identify some details of the local cultural traditions. These findings allow, in some cases, to determine the characteristic features of the period. For example, it is known that aesthetic features are largely reflected in the decoration of the burial ceremony and grave goods.
\end{abstract}

It is particularly noteworthy that the paintings on ossuaries were associated with Zoroastrianism by the early researchers. Art historians of the Soviet Era stated that the fact that such paintings were made on ossuaries caused them to be associated with Zoroastrianism. For them, the burial tradition of the Zoroastrians of the Iranian Highlands, who buried bones in clay ossuaries decorated with pictures, was an example of this. On the other hand, it is known that mourning for the dead is forbidden in the orthodox Zoroastrianism. This indicates that Zoroastrianism in the West Turkestan region was not sanctified and probably had its own ritual features, including elements of various nomadic cultures. In general, the Tok-Kala pictorial ossuary testifies to the existence of a special form of Zoroastrianism in the Early Medieval Central Asia, at least distinguished by burial practice.

The sacred symbols and images, which are the elements of the visual art on the ossuary in question, testify to the existence of religious beliefs about the afterlife, which will continue to preserve the individuality of the soul among the people of Khwarezm. The symbolism used enabled the painter to saturate the content of his works of art with a deep meaning. In addition, it is understood that the characters depicted in this ossuary carry a Turkic identity. In this study, we can obtain information about the external appearance of the Turks based on the examination of the extensive material (visual, ethnographic, anthropological and written evidence) accumulated to date and the analysis of the hairstyles and costumes of the characters on the Tok-Kala ossuary. Analysis of the historiographic material makes it possible to conclude that the Tok-Kala ossuary was poorly described by the Soviet art critics. Existing publications have uncovered some unfounded conclusions regarding the gender of the characters, based on long hairstyles and braids. Thus, it is determined that the Turkic men of the Gokturk Period have one or more braids, and the analysis of the costumes of the depicted characters emerges as the most reliable evidence of their gender. The depiction of the mourning ritual and burial ceremony on the ossuary is also understood to be a kind of "secondary modeling system" that only the bearer of a particular culture can understand. Researchers, on the other hand, can only explain and interpret the language of visual signals to a limited extent.

Keywords: Göktürk, Khorezm, Ossuary, Zoroastrianism, Clothing, Hair Braiding, Mythology.

\section{GíRiş}

Türkler, Erken Orta Çağ Orta Asya'sında konar-göçer ve yerleşik tarım medeniyetlerinin gelişiminin özelliklerini büyük ölçüde belirleyen en parlak konar-göçer topluluklarından biriydi. Ancak Eski Türk kültürünün doğuşu ve yayılıșının tarihi ve bu bölgedeki yerleșik tarım kültürleri üzerindeki etkisi, mevcut zengin tarihyazımsal temele rağmen, araştırmacılar arasında hâlâ büyük tartışmalara neden olmaktadır. Eski Türklerin kültürü üzerine tarih yazıcıllğı, önemli miktarda arkeolojik ve yazılı kaynaklarla temsil edilmektedir. Çin yazılı kaynakları, Erken Orta Çağ Türk tarihinin çeşitli yönlerinin yeniden inşasının temeli sayılmaktadır. Bununla birlikte, bu bilgilerin parçalı halde olması ve onlardaki bazı yanlışlıkları, diğer daha objektif ve nesnel kaynakların, yani arkeolojik, özellikle de Türklerin mezar ve anıt komplekslerinin kullanılması ihtiyacını belirlemektedir.

Kronolojik olarak, Türk sanat geleneklerinin bölgeye nüfuz etmesinin ve yerel sanatla, örneğin Soğd ile etkileşiminin ilk aşamasının, araştırmacılar tarafından 6. ile 9. yüzyıllar arasında belirlendiği tespit edilmiştir. Bu kronoloji, oldukça doğru bir şekilde atfedilen ve erken orta çağ bozkır kültürüyle ilgili olan sanat ve zanaat 


\section{MALİKA TUKHTAYEVA}

nesnelerine dayanmaktadır. ${ }^{1}$ Türk unsurlarının daha ayrıntılı bir şekilde incelenmesi ve tanımlanması ile yerel kültürel geleneklerin bazı detaylarının belirlenmesi için arkeologların ve sanat tarihçilerinin hizmetine sunulan çok sayıda arkeolojik eser bulunmaktadır. Bu bulgular, bazı durumlarda dönemin karakteristik özelliklerini belirlemeye izin vermektedir. Örneğin, estetik özellikler, defin töreninin ve mezar eşyalarının süslenme biçimine büyük ölçüde yansıması olarak bilinmektedir. Bu bağlamda, araştırmanın konusu, Harezm'deki Tok-Kale yerleşiminde ele geçirilen ve üzerine "merhum için yas" sahnesi çizilen bir ossuar, yani ölülerin kemiklerini barındıran seramik kutuyla ilgilidir. Ossuarın benzersizliği, onu süsleyen resmin Harezm geleneği ile Türk-Soğd etkisinin bir kombinasyonunu taşıması gerçeğinde yatmaktadır (Resim 1). ${ }^{2}$

\section{Konunun İncelenmesi}

Tok-Kale anıtındaki arkeolojik ve tarihi araştırmalar geçen yüzyılda başlamıştır. Kalenin oldukça ayrıntılı bir açıklaması, Çarlık Rusyası Yarbayı A. Grebenkin tarafından Amu Derya Bölümü Başkanı N. I. Ivanov’a yazdığı mektupta yapılmıştır. Bu açıklama da A. V. Kulbars tarafindan yayınlanmıştır. ${ }^{3}$ Tok-Kale anıtından başka araştırmacılar da bahsetmiş ${ }^{4}$ ve bu anıtla ilgili efsaneler Y. G. Gulamov tarafindan aktarılmıştır. ${ }^{5}$ TokKale'nin ilk arkeolojik araştırmaları 1946 yılında S. P. Tolstov tarafından yapılmıştır. S. P. Tolstov, özellikle bu sit alanının çok katmanlı yapısına dikkat çekmiştir. Bu anıtın çalışmasına önemli bir katkıyı, Tok-Kale yerleşiminde uzun yıllar süren arkeolojik araştırmalarının sonucu olan A. V. Gudkova'nın eseri sağlamışıtır. ${ }^{6}$ Anıtın araştırmalarına adanmış bir monografta A. V. Gudkova, 7.-8. yüzyıla ait kaymaktaşı ossuarlardaki resimlerin yorumunun yanı sıra önemli sayıda antik Harezm metinlerinin de yorumunu vermiştir. Bunun yanında Güney Aral Gölü bölgesindeki ossuar defin töreninin kökeni ve gelişimine ayrılmış özel bir çalışmanın Y. A. Rapopport'a ait olduğu belirtilmelidir. ${ }^{7}$

\section{Tok-Kale Ossuarı}

Tok-Kale yerleşimi, Özbekistan'a bağlı Karakalpakistan (Özerk) Cumhuriyeti başkenti Nüküs şehrinin 14 km kuzey batısında, küçük bir doğal Toktau (Tok-Dağ) tepesi üzerinde yer almaktadır. Tepenin eteğinin batı tarafında eski bir nehir yatağı bulunmaktadır. Tok-Kale sit alanı birkaç bölümden oluşmaktadır. Bunlar, tepenin üst kısmında antik bir kalenin kalıntıları, tepenin doğu tarafında ona bitişik bir müstahkem Göktürk Dönemi yerleşimi ve tepenin güney yamacında (bugün bir Müslüman mezarlığı bulunan) tahkim edilmemiş bir yerleşimin kalıntılarıdır. Anıtın toplam alanı 8 hektardan biraz fazladır. Yerleşimin kendisi araştırmacılara göre, aslında Harezm'in çevresinde zamanında bir askeri sınır tahkimatı rolünü üstlenmiştir. Toktau'nun kuzeydoğu ve doğu yamaçlarındaki Göktürk Dönemi yerleşiminin duvar kalıntılarının dışında, içine ossuarları yerleştirilen bir naus, yani ossuar mezarlığından oluşan geniş bir alan (yaklaşık 4 hektarlık bir alan) araştırılmıştır. İlgimizi çeken ossuar No.2'lu naus (4. Kazı alanı) kazısı sırasında bulunmuş̧ur. ${ }^{8}$

Tok-Kale'de yapılan kazılar sonucunda bulunan ossuar yamuk şeklindedir. Dikdörtgen gövdesi dört ayak üzerine oturtulmuş ve üstte köşeleri yuvarlatılmış bir kapakla kapatılmıştır. Monokrom (tek renkli) boyama, ossuarın ve kapağın tüm ön tarafını kaplamaktadır. Resim, üst (kapak) ve alt (ossuar gövdesi) parçalara bölünmüş tek bir kompozisyon olup ölen bir kişi için bir yas sahnesini gösterir. Ölen kişi, kompozisyonun ortasında, başlıklı bir yatakta yatmaktadır. Uzun beyaz bir kaftan ve koni şeklinde uzun bir başlık giyiyor, bu da merhumun önemli bir sosyal statüsü olduğunu gösteriyor olmalıdır (Resim 2, 3). L. Evtyukhova, Eski Türkler arasında yüksek sosyal statünün bir işareti olarak, kesik koni şeklinde benzer başlıklar hakkında bilgi vermiştir. ${ }^{9}$

Resimde ölüm yatağının sağında ve solunda yas tutanlar yer alır; yatağın aşağı kısmında da biri sağda, ikincisi solda oturan figürler bulunmaktadır. Aralarında, sahnenin ön planında (ossuarın alt kısmında),

\footnotetext{
${ }^{1}$ Özbek sanat eleştirmeni A. Hakimov'un belirttiği gibi, “Türk boylarının ve halklarının bölgeye (Türkistan'a) nüfuzu daha erken dönemlere tarihlenebilir" ve özellikle "sanatta dönemlendirme ve etnojenez sürecinin kronolojik olarak eşzamanlı olmadlğını" öne sürmektedir. Bkz. Hakimov A. Iskusstvo i remesla tyurkskih narodov Central'noj Azii v kontekste istoricheskogo vzaimodejstviya osedlo-zemledel'cheskih i nomadicheskih kul'tur // Central'naya Aziya v epohu srednevekov'ya i novogo vremeni: obshchestvo, kul'tura, istochniki / pod red. D. Alimova, F. Shvarc. - Tashkent: Akademnashr, 2019. s. 320.

${ }^{2}$ Ossuar şu anda I. V. Savitskiy Karakalpakistan Devlet Müzesi'nde sergilenmektedir.

${ }^{3}$ A. V. Kul'bars, Amu-Dar'i Nizov'ya, Opisaniya po sobstvennym issledovaniyam v 1873 g, Zapiski Russkogo geograficheskogo obshchestva po obshej geografii, C. IX, SPb., 1881, s. 451-452.

${ }^{4}$ S. P. Tolstov, Po sledam drevnekhorezmijskoj civilizacii, Moskva, Izd-vo AN SSSR, 1948; E. E. Nerazik, Yu. A. Rapoport, Kuyuk-kala v 1956 g., MHE, Izd-vo AN SSSR, C. 1, Moskova 1959.

${ }^{5}$ YA. G. Gulyamov, Istoriya orosheniya drevnego Horezma, Tashkent Izd-vo AN UzSSR, 1957. s. 33.

${ }^{6}$ A. V. Gudkova, V. N. Yagodin, "Arheologicheskie issledovaniya na gorodishche Tok-kala v 1959 g." Obshchestvennye nauki v Uzbekistane, 1961, S.5; A. V. Gudkova, V. N. Yagodin, Arheologicheskie issledovaniya v pravoberezhnoj chasti priaral'skoj del'ty AmuDar'i v 1958-1959 gg., MHE, C. 6, Moskova 1963.

${ }^{7}$ Yu. A. Rapopport, Iz istorii religii drevnego Horezma, Moskova 1971.

${ }^{8}$ A. V. Gudkova, Tok-kala. Izd-vo Nauka, Tashkent 1964, s. 83.

${ }^{9}$ L. Evtyuhova Eski Türklerin başlıklarını dört türe ayırır: yuvarlak, muhtemelen kürklü şapkalar, kesik külah biçimindeki başlıklar, kulaklık gibi şapkalar ve sivri uçlu özel şapkalardır. Bkz. L. A. Evtyuhova, Kamennye izvayaniya YUzhnoj Sibiri i Mongolii, MIA,C. 24, Moskva 1952, s.104.
} 


\section{GÖKTÜRK DÖNEMİ HAREZM GÖRSEL SANATINDA TÜRK KIMMLIĞİ (TOK-KALE OSSUARI ÖRNEĞINDE)}

muhtemelen bir ateş sunağının oldukça stilize olduğu varsayılan bir görüntüsü vardır. Üst kısımda, ayrıntıları sola ve sağa doğru ayrılan tipik Soğd "darmadağını" yarı palmetler (yoncalar) çizilmiştir. Belki de sağında duran ve elini uzatan karakterin diz çökmüş duruşu, ortadaki objenin bir sunak olmasıyla bağlantılıdır. Ellerini göğsüne veya kafasına kaldırarak yas tutanların, keder belirtisi olarak kendilerine vurmaları ve saçlarını çekmeleri muhtemeldir. ${ }^{10}$ Defin sahnelerinde elleri başlarına doğru yukarı kaldırılmış insan figürleri daha önce araştırmacılar tarafindan benzer şekilde yorumlanmıştı. ${ }^{11}$

Benzer jestler, resmin üst kısmındaki, ossuarın kapağındaki -solda dört karakter ve sağda üç karakterkarakter tarafından da gösterilmektedir. Aralarında, teknik olarak merkezde, ölen kişinin üstünde (daha doğrusu ondan arka planda) bulunan dikdörtgen bir açıklık vardır. Bu belki de son derece şematik olarak işlenmiş bir mimari yapının parçasıdır. Açıklık siyah ve kırmızı boyalarla iyi çizilmiş; kapı aralığının üst kısmında yanlara doğru uzanan yatay kırmızı şeritle, muhtemelen binanın tepesini göstermektedir. Açıklı̆ı̆ın üst köşelerinden, açık kanatları andıran stilize yarım palmetler yukarıya ve yanlara doğru uzanmaktadır. Aralarındaki merkezde, açıklk güneş diskli bir hilal ile taçlandırılmıştır (yarım yayın üzerinde bir daire, muhtemelen bir yıldız). ${ }^{12}$

Tarif edilen açıklık, sözde, ölen kişinin ruhunun gideceği öbür dünyaya (göklere) bir giriş portalını tasvir etmektedir. Kapının üzerinde bir güneş diski (yıldız) bulunan bir hilal, ruhu bekleyen yeni bir yaşam döngüsünün başlangıcının vaadi olan ilahi bir sembol olarak yorumlanabilir (Resim 4, 5, 6). Bu semboller, Orta Doğu, İran ve Orta Asya'nın eski kabile ve halklarının mitolojisinde eski köklere sahiptir. Mazdeizm'de, ayın ve güneşin kutsal işaretleri -yay üzerinde bir daire- kötülük güçlerinden kurtuluşa giden yolu gösteren rehberlerdi. $\mathrm{Bu}$ işaret, Maniheist Türkler arasında kutsal bir anlam taşıyordu. ${ }^{13}$ Eski Türklerin mitolojik varoluş kavramına göre, ölüm, yeni yaşamın kaynağıydı ve kişi ölünce onun ruhu sadece niteliksel olarak farklı bir duruma geçerdi. ${ }^{14}$ Buna göre ossuarın ikonografisi, ruhu kurtarma ritüeline ilişkin Mâni geleneğinin tüm ayırt edici özelliklerine sahiptir.

Orta Asya Türk kültürünü inceleyen birçok araştırmacı, güneş diskli hilalin hâlâ bu bölgedeki ulusal dekoratif süslemelerin ve devlet sembollerinin ayrılmaz bir parçası olduğunu belirtmektedir. Bu sembol, Orta Asya'da M.Ö. 4 binde ortaya çıkışı İran yaylalarından gelen göçmenlerle ve daha sonra Mezopotamya kültürüyle ilişkilendirilmektedir. Benzer görüntüleri Buharalılara veya Soğdlulara ait An Jiya’nın Türk mezarlığında da görebiliriz. ${ }^{15}$

Aşağıda, ossuarın ayak kısmında, tüm sahne, görünüşe göre anlamsal bir yük taşımayan, ancak dekorasyon işlevini yerine getiren üçgen şeklinde bir süs şeridi ile tamamlanmıştır. V. E. Sarianidi, Güney Türkmenistan antik seramiklerinde üçgen-piramitlerin görüntüsüne ilişkin iki hipotezi öne sürmektedir. Birinci varsayıma; bu bir tanıının (eski bir tarım tanrısının) bir tür piktogramı olabilir ve ayrıca Sümer yazısındaki benzer işaretlerin "dağ kelimesi anlamına geldiğidir. İkinci varsayım ise; bu tür piramitlerin görüntüsü, çok basamaklı tapınakzigguratlara bir şekilde uzaktan benzediğidir. ${ }^{16}$

Esasen ziggurat da bir dağdır, sadece çok daha kutsaldır. Bu piramitleri bir ziggurat olarak yorumlayabilirsek, burada defin töreninin gerçekleştĭgi mimari yapının şematik bir temsilini görebiliriz ve o zaman da doğu halklarının (Mezopotamya, Mısır) antik mitolojik inançlarına başvurabiliriz. Yani zigguratı "cennete götüren bir merdiven” olarak yorumlayabiliriz. Ossuarın ayak kısmındaki üçgenler veya piramitler, dağların geometrik çizimlerine benzer ve bu tür piramitler de kült tapınaklarına -zigguratlara- benzer.

\section{Karakterler ve Görünüşleri}

Ölünün etrafinda toplanan 14 karakterin tamamı Türk kıyafetlerine ve saç stillerine sahiptir. Buradaki önemli bir unsur, kompozisyonda erkek ve kadın figürlerinin yerleştirilmesidir. Onlar iki sıra halinde iki grup

\footnotetext{
${ }^{10} \mathrm{Bu}$ tören aynı zamanda Eski Türklerin Kaos hakkındaki inançlarına da tanıklık ederki, bu inanca göre, kadınlar tarafindan "yas tutma (ağlama)" ayini aracılığıyla, bir tür belirsiz yapısal mekanın (Kaosun) düzenlenmesi gerçekleştirilir. Ölen kişi, ataların dünyasına yaklaşarak törenin yine bir aşamasından geçer. Bkz. Tradicionnoe mirovozzrenie tyurkov Yuzhnoj Sibiri. Chelovek. Obshchestvo / L'vova L., Oktyabr'skaya I. V., Sagalaev A. M., Usmanova M. S. - Novosibirsk: Nauka 1989.

${ }^{11}$ Sh. M. Shukurov, K analizu principov ikonografii v izobrazitel'nom iskusstve Srednej Azii. Sb. statej. Srednyaya Aziya $v$ drevnosti $i$ srednevekov'e, Nauka, Moskva 1977. s. 104.

${ }^{12}$ Zerdüştlüğün birçok takipçisi, güneşin Ahura Mazda'nın kişileşmesi olduğuna inanıyordu, o yüce bir varlığın statüsüne sahiptir. Ay kültü İran dini alanında da mevcuttu. Hilalle çevrili bir kürenin (daire) görüntüsü, Anahita'nın ikonografik sembollerinin karakteristiğidir. Bkz. Yu.A. Rapoport, “Ob izobrazhenii na Bartymskom blyude, najdennom v 1951 g.”, Sovetskaja Arheologiya, 1969, S.2. s. 59. Anahita'nın amblemi, Harezm anıtlarındaki ossuarların kapaklarını, Pencikent, Varahşa, Koço ve Kızıl anıtsal resimlerini süslüyor.

${ }^{13}$ N. I. Rybakov, "Solnce i luna v petroglifah iyusskih stepej”, s. 67. https://cyberleninka.ru/article/n/solntse-luna-v-petroglifah-iyusskihstepey/viewer

${ }_{14}$ Tradicionnoe mirovozzrenie tyurkov Yuzhnoj Sibiri, Chelovek. Obshchestvo / L'vova L., Oktyabr'skaya I. V., Sagalaev A. M., Usmanova M. S. - Novosibirsk: Nauka 1989, s. 216.

${ }^{15} 2001$ 'de Çin'in Wenwu bölgesinde bulunan bir mezarlıktaki taş heykeli üzerinde yapılan bir kısma görsel. An Jie'nin granit mezar yatağı (MS 579), Çin, Xi'an, Kuzey Zhou hanedanı dönemi, An Jie mezarı.

${ }^{16}$ V. I. Sarianidi, Tajny ischeznuvshego iskusstva Karakumov, Moskova Nauka 1967, s. $96-96$
} 


\section{MALIKA TUKHTAYEVA}

olarak dururlar. Ossuar kapağında kadınlar sağda, erkekler solda; ossuarın gövdesinde (sahnenin alt kısmı) ise, kadınlar solda ve erkekler ölünün sağındadır.

Daha önce, A. V. Gudkova ve S. M. Şükürov'un yorumuna göre, kadınlar ve erkekler arasındaki farkın kadınların uzun saçlı ve erkeklerin kısa saçlı olmalarıyla belirtilmiştir. ${ }^{17}$ Ancak son araştırmalar, Eski Türkler arasında saç stillerinin kısa, omuzlara düşen, bir uzun örgü ve iki veya daha fazla örgü olarak dört tipe ayırıldığını gösterir ve uzun örgülerin genellikle Türk erkekleri tarafından kullanıldığını kaydeder. Bu da Ş. M. Şükürov'un yorumunun yanlış olduğuna işaret etmektedir. Uzmanlar, Eski Türklerin saç modelleri hakkında iki çelişkili görüşü öne sürmektedir. Çoğu araştırmacının belirttiği bakış açısına göre, Göktürk Kağanlığı Döneminden itibaren Türk erkekleri uzun örgülü saç stilini kullanırlardı. Aynı zamanda, Biçurin ve Agafiy’e atıfta bulunan bazı araştırmacılar (A. D. Grach, M. I. Artamonov), Orta Asya Türk erkeklerinin omuzlarına kadar uzun saç stilini kullandığı konusunda ısrar etmektedir. Bu tartışmanın ayrıntılarını atlayarak, Efrasiyab’ın (eski Semerkant) Erken Orta Çağ duvar resimlerinde kanıtlandığı gibi, örgü takmanın Orta Asya Türklerinin özelliği olduğunu not edebiliriz. Araştırmacılardan S. I. Vainştein ve M. V. Kryukov, Avrupa'nın güney doğusundan Orta Asya'ya kadar geniş bir bölgede örgülerin Türklerin önemli etnik özelliklerinden biri olduğu gerçeği lehinde çok ikna edici argümanlar vermektedirler. Özellikle Xin Tang Şu'nun yazarı, Güneydoğu Asya halklarından birinin geleneklerini anlatırken “örgülerini Türkler gibi örüyorlar” ifadesini kullanmaktadır. ${ }^{18}$ Bir veya birkaç örgü, Türk soylu erkekleri için etnik bir işaret görevini yapıyordu. Böylece bu işaret Türkleri "batı ve kuzey barbarlarından" ayırıyordu. ${ }^{19}$ Bunun tespiti Yedisu (Yettisuv) bölgesindeki Eski Türklere ait örgülü erkekleri temsil eden taş heykelleri (balbal) ile doğrulanmaktadır. Tok-Kale’deki ossuarda tasvir edilen karakterlerin Eski Türk balbalları ve Efrasiyab duvar resimlerindeki Türk savaşçıları ile benzerliğinden şüphe yoktur (Resim 7, 8, 9). ${ }^{20}$

Tok-Kale ossuarının üzerinde çizilen resimdeki karakterlerin açıklamasına dönersek, sanat tarihçilerinin, özellikle S. A. Yatsenko'nun son araştırmalarına göre, karakterlerin cinsiyetini belirlemede kilit noktanın giyim olduğu öne sürülmektedir. ${ }^{21}$ En üst sıradaki kadınlar, geniş dikdörtgen şeklinde boyun deliği olan veya göğüs kısmına konulmuş özel eki olan düz kırmızı elbiseler giydikleri görülmektedir. Omuzlarında uzun pelerinler olabilir, ancak ayırt edilmesi zordur. Kompozisyonun alt kısmında yer alan kadınların omuzları ve gögüslerin üst kısmı çıplaktır; bu da muhtemelen ritüel darbeler verilmesi ve yaralanması amacıyla özellikle yapılmıştır. Takım elbiselerinin göğüs bölgesindeki üst kısmına siyah renkle çizilen düzensiz çerçevenin (kontürün), büyük ihtimalle, yırtık giysi parçaları olduğu düşünülmektedir.

Yası tutulan kişinin, kıyafetlerine (beyaz kaftan) ve uzun örgüsüne bakıldığında erkek olduğu anlaşılmaktadır. Ölünün yanında yerde oturan ve bacakları altlarına sıkışmış üç figür de özellikle kayda değerdir. Bunlar muhtemelen “nasassalar”lardır. ${ }^{22}$ Sunağın solunda oturan ve kısa kolsuz bir kaftan giyen karakter, sanki kaldırılmış eliyle ölünün örgüsüne dokunuyormuş gibi gösterilmiştir. Onun kaftanının göğüsteki yanları birleşmiyor ve onun altından giyilmiş kollu gömlek görülmektedir.

İlk sıradaki Türk erkekleri yarı açık kaftan giymişlerdir. Kaftanın alt kısmı iki renkli kumaşın kombinasynundan oluşturulmuştur. Erkekler, muhtemelen kakma olan (metal aksesuarları olmayan) kemer bağlanmış ve onların belleri keskin bir şekilde vurgulanmıştır. Kompozit kuşaklar, Türk konar-göçer ortamında Orta Asya'dan Batı Asya'ya ve Doğu Avrupa bozkırlarına kadar yaygındı. ${ }^{23}$ Sayan-Altay ve Moğolistan'ın neredeyse elli heykelinde işlemeli kemerler işaretlenmiştir. ${ }^{24}$

Ölen kişinin ayaklarının dibinde duran bir Türk’ün kıyafetleri onu diğer karakterlerden ayırmaktadır. Onun kaftanında iki siyah renkli üçgen şeklinde yakacı̆̆ı olan çevrilmiş geniş yakası gözlemlenir. Benzer yakalar (muhtemelen kürkten yapılmış) Altay'daki Türk heykellerinde görülebilir. ${ }^{25} \mathrm{Bu}$ stil detayı, Efrasiyab’ın pişmiş topraktan yapılan heykelciklere (terrakota) ve duvar resimlerine bakılırsa, yalnızca 7. yüzyılda ortaya çıkmaya

\footnotetext{
${ }^{17}$ Shukurov Sh. M. age, s. 104.

${ }^{18}$ S. I. Vajnshtejn, M.V. Kryukov, “Ob oblike drevnih tyurkov”, Tyurkologicheskij sbornik, Izd. Nauka Moskva,1966. s. 181.

${ }^{19}$ Vajnshtejn, M.V. Kryukov, agm, s. 181.

${ }^{20}$ En eski ayrıntılı resimli görüntülerin materialleri, Türk kostümü tarihi için özel bir değere sahiptir. Uzun bir süre boyunca, Eski Türklerin kostümü, esas olarak höyükler ve mezar kutsal alanlarındaki en eski oyma taş görüntülerinden biliniyordu. Bu tür heykeller (balballar) detaylı çalıșılmıștır Bkz. Evtyuhova 1952; Șer 1966; Kubarev 1997; 2005, Resim 5-10; Dosımbayeva 2013.

21 S. A. Yatsenko, “Drevnie tyurki: muzhskoj kostyum v kitajskom iskusstve 2-j pol. VI - 1-j pol. VIII vv. (Obrazy “Inyh”)”, https://swordmaster.org/uploads/2011/oldturks/ancient_turks_costume_in_a_color_images.pdf

22 “Nasassalar”lar - Zerdüştlük inancına merhumun yanında bir sedye taşıyan defin töreninin yönetici gurubudur (Zerdüştlük toplumunda özel bir sosyal kesimdir). "Nasassalar”lar cesedi yıkar, beyaz kefen giydirir ve kollarını gögüuslerinin üzerine katlardı. Ölen kişiye sadece onlar dokunabilirdi. Diğerleri için, ölüye dokunmak uzun bir arınma ritüelini gerektiridi; ölenin yakınları ona sadece uzaktan bakabilirdi. Bkz. E. A. Doroşenko, Zoroastrijcy v Irane (Istoriko-etnograficheskij ocherk), Moskva Nauka, 1982. s. 57.

${ }^{23}$ V.I. Raspopova, “Nabornyj poyas Sogda VII -VIII vv.”, Sovetskaja Arheologiya, 1965, S.4, s. 78-91.

${ }^{24}$ L. Evtyuhova, S. Kiselev,” Otchet o rabotah Sayano-Altajskoj arheologicheskoj ekspedicii v 1935 g.”, Trudy Gos. istorich. muzeya, S. XVI, 1941, s. 108; A.D. Grach, “Arheologicheskie raskopki v Mongun-Tajge i issledovaniya v central'noj Tuve”, Trudy TKEAN, S. 1, Moskva Leningard,1960, Cetvel.

${ }^{25}$ G. V. Kubarev, Kul'tura drevnih tyurkov Altaya (po materialam pogrebal'nyh pamyatnikov), Novosibirsk. 2005. Resim 6, 13.
} 


\section{GÖKTÜRK DÖNEMİ HAREZM GÖRSEL SANATINDA TÜRK KIMLİ̆Ğ (TOK-KALE OSSUARI ÖRNEĞINDE)}

başlamış̧ır. Böyle giysi yakaları Türk soylularının geleneksel unsuru olarak daha sonraki döneme ait "terrakota" heykelciklerinde görülür (Resim 8, 9).

Kompozisyonun sol üst kısmı yani ossuarın kapağında yer alan Türk erkeklerinde biraz farklı yakaları olan kaftan türünün olduğu açıkça görülür. Bu tür giysiler, soyluların hizmetkarı olan alt sınıf Türkler tarafindan giyildiği bilinmektedir. ${ }^{26}$ Yaka kumaşının arka tarafi, genel arka planın renginden pek ayırt edilmez (burada sanatçı sadece taslağı işaretlemiş̧ir). Moğolistan ve Tuva bölgesinin Sarıg-Bulun yerleşiminde bulunan bazı Türk heykellerinde de benzer kıyafetler göze çarpmaktadır. ${ }^{27}$

Ossuarda çizilen erkeklerin giyimi kırmızı, beyaz ve kısmen siyah olan üç ana renkte boyanmıştır. Bu da Çin terrakotaları ve Efrasiyab duvar resimlerindeki görüntülere bakılırsa 7.-8. yüzyılara ait Türk erkek giysisinin renk şemasına uygundur. Efrasiyab sarayında açılan "Elçiler Salonu"nun duvar resimlerindeki Türkler, rengarenk olmayan sade, tek renkli kıyafetler giymişlerdir. Bu hal onların giysilerinde süslemelerin tamamen olmadığı anlamına gelmez, Türklerin giysileri arka plandan renklerle değil, 1şık ve gölgeler oyunuyla farklanmışıtır.

Tüm karakterler, uzun sivri burunlu yumuşak botlar giymişlerdir (Eski Türkçede "içig" denilen ayakkabı türü). Takılardan bilezikler ve küpeler görülebilir. Küpeler Türk kültürünün karakteristik bir unsuru olarak hem kadınlar hem de erkekler tarafindan takılmıştır. Bronz, gümüş veya altından yapılan küpeler, Eski Türk Döneminde Avrasya'nın Kuzey Kafkasya'ya kadar olan konar-göçerleri arasında çok yaygın olmuştur. Daha sonra bu prestijli aksesuar, gücün ve iktidarın sembolü olarak yorumlanmıştır. Türk taş heykellerinde (balballarda), bir veya iki kulakta küpeler ${ }^{28}$, boyunlarda tork veya kolyeler de tasvir edilmiştir (Resim 11) ${ }^{29}$

Tok-Kale ossuarındaki erkeklerin kıyafetleri ve saç stilleri, uçlarda birleştirilmiş uzun saç bukleleri, küpeler, dekoratif dizgi kemerleri, kendine özgü "oryantal” (Doğu'ya ait olan) kaftan-bornozlar, uzun sivri burunlu ayakkabılardan oluşup, kesinlikle Türk kostümünün otantik unsurları sayılır. Bununla birlikte, yakalı uzun kaftanlar giyme geleneği, kesin olarak Soğdluların karakteristiğidir. Muhtemelen 7. yüzyılda Türk kıyafeti, Türklerin yoğun göçleri, sosyal yapılarının karmaşıklı̆ğ , Çin, Soğd ve İran kültürlerinin etkisi ile ilişkili olarak açıkça birçok değişikliğe uğramıştır. Bu,bir yandan, Türklerin yayılım alanına giren son derece gelişmiş yerleşik devletlerin halklarından prestijli giyim unsurlarına Türk seçkinleri tarafindan taklit etme arzusundan kaynaklanmıştır. Öte yandan, bazen yabancı kültürel etkilere karşs dirençlerini kışkırtmıştır. O dönemde Soğdlular ve Türkler arasındaki kültürel ve siyasî iliş̧kilerin doğası değişiyordu, ancak kostüm de dahil olmak üzere gündelik kültürde karşılıklı etkinin artması şüphesizdir.

Görünüşe göre, sanatçı kendisinin Tok-Kale ossuarındaki resminde çağdaş defin töreninin ayrıntılarını gerçekçi bir şekilde aktarmaya çalışmıştır. Ağlayan erkekler ve kadınlar ölünün etrafını sarmış, saçlarını ve kıyafetlerini yırtıyor, ritüel olarak kendilerini göğsüne ve kafasına vuruyor veya tırmalıyor. Sanatçının, sahne katılımcılarının bireysel özelliklerini aktarma arzusu da izlenir. Bireysel unsurları şüphesiz aynı zamanda karakterlerin süsleri ve kıyafetlerinden fark edilmektedir. Ossuardaki görüntüler, Eski Harezmlilerin görünümünü değerlendirmek için eşsiz bir kaynak olabilmektedir. Genel olarak sahne, yerel halkın hayatından defin töreni gibi ortak bir hikâyeyi yansıtır ve aynı zamanda da mitolojik unsurlar hakkında bilgi vermektedir.

Kompozisyon şemasının üst ve alt parçalara bölünmesi, muhtemelen hem Harezmlilerin hem de Türklerin dini ve mitolojik anlayışlarının karakteristiği olan dikey bir dünya modeli fikrini aktarmaktadır. Aynı zamanda, bu şema anlamsal karşıtlıkların ikili ilkesini yansıtmaktadır -üst ve alt, gökler ve dünya-. Kompozisyonun merkezinde, altta ölen kişinin bulunduğu ölüm yatağı ve üstte "kanatlı" portal ve "ay-güneş" kutsal sembolü yer almaktadır. Bu kompozisyon yapısı, Türk ve İranlı halkların kültüründe dünyanın mitolojik modelinin ana parametrelerine karşlık gelmektedir. Genelde bu anlayışa göre, organize edilmiş mekânın (varlı̆̆ın) bir merkezi olur (ortada dünya ağacı ya kutsal bir dağ veya dünyanın göbeği), doğal olarak da bu merkezden uzak olan alanlar olur.

\section{Sahnenin Yorumu}

Tok-Kale ossuarında çok figürlü kompozisyona sahip olan bir resmin olması onu benzersiz kılmaktadır. Ancak, bu ossuar elbette ki Harezm'deki tek buluntu değildir. Tok-Kale'de bir yas sahnesi olan başka boyalı ossuarlar da bulunmuştur. Küne-Uvaz’da (Köhne Uvaz) kırmızı ve siyah renkli boyalı resimleri olan birkaç

\footnotetext{
${ }^{26}$ S. A. Yatsenko, "Drevnie tyurki: muzhskoj kostyum v kitajskom iskusstve 2-j pol. VI - 1-j pol. VIII vv. (Obrazy "Inyh”)", https://swordmaster.org/uploads/2011/oldturks/ancient_turks_costume_in_a_color_images.pdf

${ }^{27}$ L.A. Evtyuhova, Kamennye izvayaniya Yuzhnoj Sibiri i Mongolii, MIA, C. 24, Moskva 1952, Resim 48, 1.

${ }^{28}$ L. Evtyuhova, S. Kiselev, "Otchet o rabotah Sayano-Altajskoj arheologicheskoj ekspedicii v 1935 g.”, Trudy Gos. istorich. muzeya, S. XVI, 1941, Resim 17, 23; S. I. Vajnshtejn, “Nekotorye itogi rabot arheologicheskoj ekspedicii Tuvinskogo NIIYALI v 1956-1957 gg.”, Uch. zap. TNIIYALI, S.VI, Kyzyl 1958, tabl. IV, Resim 134, 135.

${ }^{29}$ Ya. A. Sher, Kamennye izvayaniya Semirech'ya. Moskva Leningard 1966. s. 11.
} 


\section{MALİKA TUKHTAYEVA}

ossuar $^{30}$, Mizdakhan (Gâur-Kale) nekropolünde defin törenini görünteleyen bir ossuar ${ }^{31}$ ve sonuncusu Tok-Kale anıtında resimleri olan birkaç ossuar bulunmuştur. Ek olarak, Pencikent’te de yas sahneleri olan boyalı ossuarların ele geçirildiği bilinmektedir. Boyalı ossuarların, kabartmalı veya oymalı kompozisyonlara sahip ossuarlardan daha az yaygın olduğu belirtilmelidir. Ancak boyalı ossuarların bulunması, ustalarının farklı malzemelerle çalışabildiği bir resim geleneğinin bölgede gelişmiş olmasından söz etmemizi sağlamaktadır.

Tok-Kale resimli ossuarları, kuşkusuz Erken Orta Çağ Harezm ahalisinin dini inançları ve defin törenleri, fiziksel görünümleri ve burada Türk etnik ve kültürel bileşeninin yayılması hakkında değerli bir kaynaktır. Soğd bölgesinde bulunan Soğd güzel sanatlarının anıtlarında Türk ve Soğd kültürlerinin karşılıklı etkisinin yansıdığ iyi bilinmektedir. Tok-Kale ossuarı, Harezm topraklarındaki benzer süreçlerin kanıtı olarak hizmet edebilir. Türk etnik özellikleri hem ölen kişinin hem de onun yasını tutan erkek ve kadınların görünümünde açıkça ifade edilir.

Araştırmacılar ayrıca, ossuarlardaki resimlerin içeriği ile Soğd gelenekleri arasındaki benzerliklere dikkat çekmektedirler. Nitekim Biruni, Soğd sakinlerinin ölülerin yasını tuttuklarını ve bu yaslara yüzlerini tırnaklayarak eşlik ettikleri hakkında yazmıştır (Resim 10). ${ }^{32}$ Eski Soğd'da bir yas ayininin varlığı Mug Dağı'nda bulunan belgelerde de bildirilmektedir. Benzer bir ritüel Türklerin de yer aldığı Pencikent resimlerindeki "Yas sahnesi"nde tasvir edilmektedir. ${ }^{33}$ V. N. Yagodin tarafindan tarif edilen Mizdakhan nekropolünde (Harezm) ele geçirilen bazı ossuarlarda katılımcıların kendilerine ritüel yaralar açtığı yas sahneleri de tasvir edilmiştir. ${ }^{34}$

P. K. Daşkovskiy ve D. V. Kultyakova’ya göre, bu tür defin törenlerinin kökleri İskit dönemine kadar uzanmaktadır. İskit kralını gömerken, İskitler kederlerini ağlayarak ve kendilerine işkence ederek, yani kendilerine yaralar vererek ve saçlarını çekerek ifade etmişlerdir. Bu tür duygusal davranışla, kaybın acısı anlamına gelmesi ve aynı zamanda toplumdaki uygunluğun (uyumun) yok edilmesi, karanlığın ve kaosun başlamasını sembolize etmiş olmalıdır. ${ }^{35}$ Ritüelin görüntüsü, araştırmacılara o dönemde bir kişinin mitolojik düşüncesinin rolünün ne kadar önemli olduğunu göstermektedir.

\section{SONUÇ}

Ossuarlar üzerinde yapılan resimlerin ilk araştırmacılar tarafından Zerdüştlük ile ilişkilendirilmesi özellikle dikkate değerdir: Resimlerin ossuarlar üzerinde yapılmış olması, onları Zerdüştlük ile ilişkilendirmemizi sağlamaktadır. Resimlerle süslenmiş kil ossuarlara kemikleri gömen İran Dağlık Bölgesi Zerdüştlerinin gömme gelenekleri buna bir örnektir. Öte yandan, Ortodoks Zerdüştlükte ölü için yas tutmanın yasak olduğu bilinmektedir. Bu durum ise, bölgemizde Zerdüştlüğün kutsallaştırılmadığını ve muhtemelen çeşitli konar-göçer kültürlerin unsurlarını içeren kendine özgü ritüel özelliklerine sahip olduğunu göstermektedir. Genel olarak, Tok-Kale resimli ossuarı, Erken Orta Çağ Orta Asyası'nda, en azından defin töreni ile ayırt edilen özel bir Zerdüştlük biçiminin varlığına tanıklık etmektedir.

Söz konusu ossuardaki görselin unsurları olan kutsal semboller ve görüntüler, Harezm ahalisinde ruhun bireyselliğini korumaya devam edecek olan öbür dünya hakkında dini inançlarının varlığına tanıklık etmektedir. Kullanılan sembolizm, ressamın sanat eserlerinin içeriğini derin bir anlamla doyurmasını sağlamıştır. Ayrıca, bu ossuarda tasvir edilen karakterlerin Türk kimliğini taşıdığı anlaşılmaktadır.

Bu çalışmada, Türklerin dış görünümü hakkında bugüne kadar birikmiş kapsamlı materyalin (görsel, etnografik, antropolojik ve yazılı kanıtların) incelenmesine ve Tok-Kale ossuarındaki karakterlerin saç stilleri ve kostümlerinin analizine dayanarak bilgilere sahip olabilmekteyiz. Tarihyazımsal materyalin analizi, Tok-Kale ossuarının Sovyet sanat eleştirmenleri tarafından yetersiz tanımlandığı sonucuna varmayı mümkün kılmaktadır. Mevcut yayınlar, uzun saç modellerine ve örgülere dayalı olarak, karakterlerin cinsiyetine ilişkin bazı asılsız sonuçları ortaya çıkarmıştır. Böylece, Göktürk Dönemi Türk erkeklerinin bir veya birkaç örgüye sahip olmaları tespit ediliyor ve tasvir edilen karakterlerin kostümlerinin analizi, onların cinsiyetlerinin en güvenilir kanıtı olarak ortaya çıkıyor. Yas ritüeli ve defin töreninin ossuar üzerinde tasviri, yalnızca belirli bir kültürün taşıyıcısının anlayabileceği bir tür "ikincil modelleme sistemi”dir. Araştırmacılar ise yalnızca görsel işaretlerin dilini sınırlı derecede açıklayabilmekte ve yorumlayabilmektedir.

\footnotetext{
${ }^{30}$ S. P. Tolstov, Horezmskaya arheologo-etnograficheskaya ekspediciya, AN SSSR v 1949-1953 g., s. 218.

${ }^{31}$ V. N. Yagodin, “Novye materialy po istorii religii Horezma”, Sovetskaja Etnografiya, 1963, S. 4, s. 102.

${ }^{32}$ Al-Beruni, Izbrannye proizvedeniya, C.I., Tashkent 1957, s. 355.

${ }^{33}$ A. M. Belenitskiy, Monumental'noje iskusstvo Penjikenta, İskusstvo, Moskva 1973.

${ }^{34}$ Al-Beruni, age, s. 41.

${ }^{35}$ Dashkovksiy P. K., Kul’tyakova D. V. Vlijaniye iranskogo religioznogo kompleksa na mirovozzrenije Yuzhnoj Sibiri i Central’noj Azii v skifskuju epohu. Mirovozrenie naseleniya YUzhnoj Sibiri i Central'noj Azii v istoricheskoj retrospektive. Barnaul. Vyp. I, 2007. S. 35.
} 


\section{GÖKTÜRK DÖNEMİ HAREZM GÖRSEL SANATINDA TÜRK KIMLIĞİ (TOK-KALE OSSUARI ÖRNEĞINDE)}

\section{KAYNAKÇA}

AL-BERUNI, Izbrannye proizvedeniya, T. I., Tashkent, 1957.

BELENITSKIY, A. M., Monumental'noje iskusstvo Penjikenta, İskusstvo, Moskova, 1973.

DASHKOVKSIY, P. K., KUL'TYAKOVA, D. V., Vlijaniye iranskogo religioznogo kompleksa na mirovozzrenije Yuzhnoj Sibiri i Central'noj Azii v skifskuju epohu, Mirovozrenie naseleniya Yuzhnoj Sibiri i Central'noj Azii v istoricheskoj retrospektive, Barnaul. Vyp. I, 2007.

DOROŞENKO, E. A., Zoroastrijcy v Irane (Istoriko-etnograficheskij ocherk), M., Izd-vo.: "Nauka” 1982.

DOSIMBAYEVA, A., Istoriya tyurkskih narodov Tradicionnoe mirovozzrenie tyurkov, Almaty. Seuvice Press, 2013.

EVTYUHOVA, L. A., Kamennye izvayaniya Yuzhnoj Sibiri i Mongolii, — MIA, C.24, Moskova 1952.

EVTYUHOVA, L., KİSELEV, S., "Otchet o rabotah Sayano-Altajskoj arheologicheskoj ekspedicii v 1935 g.”, Trudy Gos. istorich. muzeya, S. XVI, Moskov1941, s.17-23,

GRACH, A. D., “Arheologicheskie raskopki v Mongun-Tajge i issledovaniya v central'noj Tuve”, Trudy TKEAN, t. 1, cetvel, Moskova-Leningrad 1960, s. 73-150.

GUDKOVA, A. V., YAGODİN, V. N., "Arheologicheskie issledovaniya na gorodishche Tok-kala v 1959 g.”, Obshchestvennye nauki v Uzbekistane, S.5, Tashkent 1961, s. 49-59.

GUDKOVA, A. V., YAGODIN, V. N., Arheologicheskie issledovaniya v pravoberezhnoj chasti priaral'skoj del'ty Amu-Dar'i v 1958-1959 gg., MHE, C.6, Moskova 1963.

GUDKOVA, A. V., Tok-kala Izd-vo Nauka. Tashkent 1964.

GULYAMOV, YA. G., Istoriya orosheniya drevnego Horezma, Izd-vo AN UzSSR, Tashkent 1957.

HAKIMOV, A., Iskusstvo i remesla tyurkskih narodov Central'noj Azii v kontekste istoricheskogo vzaimodejstviya osedlo-zemledel'cheskih i nomadicheskih kul'tur. Central'naya Aziya v epohu srednevekov'ya i novogo vremeni: obshchestvo, kul'tura, istochniki, Akademnashr, Tashkent 2019, s. 320-330.

KUBAREV, G. V., Kamennye izvayaniya Altaya, Kratkij katalog, Novosibirsk, Gorno-Altajsk 1997.

KUBAREV, G. V., Kul'tura drevnih tyurkov Altaya (po materialam pogrebal'nyh pamyatnikov), Novosibirsk 2005.

KUL'BARS A. V., NIZOV'YA Amu-Dar'i., Opisaniya po sobstvennym issledovaniyam v 1873 g. Zapiski Russkogo geograficheskogo obshchestva po obshej geografii, C. IX, Sant Petersburg 1881.

MAURER TRINKHAUS K., Mortuary Ritual and Mortuary remains' Current Anthropology, No.25, Vol.5, Newyork 1984, s. 674-690.

NERAZIK, E. E., RAPPOPORT, Yu. A., Kuyuk-kala v 1956 g., MHE, Izd-vo AN SSSR, vyp. 1, Moskova 1959.

RAPPOPORT, Yu.A., “Ob izobrazhenii na Bartymskom blyude, najdennom v 1951 g.”, Sovetskaja Arheologiya, S.2, Moskova 1962 s. 50-60.

RAPPOPORT, Yu. A., Iz istorii religii drevnego Horezma, Moskova 1971.

RASPOPOVA, V. I., “Nabornyj poyas Sogda VII -VIII vv.”, Sovetskaja Arheologiya, Moskova1965, S.4, s.7892.

RYBAKOV, N. I., Solnce i luna $v$ petroglifah iyusskih stepej. Kransoyarsk, Petrovskaja akademija nauk i iskusstv, Moskova 2008.

SARIANIDI V. I., Tajny ischeznuvshego iskusstva Karakumov, Moskova Nauka, 1967.

SHER Ya. A., Kamennye izvayaniya Semirech'ya, Moskova Leningard, 1966.

SHUKUROV Sh. M. K analizu principov ikonografii v izobrazitel'nom iskusstve Srednej Azii. Srednyaya Aziya $v$ drevnosti i srednevekov'e. Moskova. Nauka, 1977, s. 102-117.

TOLSTOV, S. P., Horezmskaya arheologo-etnograficheskaya ekspediciya AN SSSR, Moskova 1949-1953. 


\section{MALİKA TUKHTAYEVA}

TOLSTOV, S. P., Po sledam drevnekhorezmijskoj civilizacii, Izd-vo AN SSSR, Moskova 1948.

Tradicionnoe mirovozzrenie tyurkov Yuzhnoj Sibiri. Chelovek. Obshchestvo, Novosibirsk Nauka 1989.

VAJNSHTEJN, S. I., KRYUKOV, M. V. Ob oblike drevnih tyurkov. Tyurkologicheskij sbornik, Moskova Nauka, 1966, ss. 177-188.

VAJNSHTEJN, S. I., Nekotorye itogi rabot arheologicheskoj ekspedicii Tuvinskogo NIIYALI v 1956-1957 gg., Uchenije zapiski TNIIYALI, vyp. S. VI, Kyzyl 1958, s.179-195.

YAGODIN, V. N. Novye materialy po istorii religii Horezma. Sovetskaja Etnografiya, Moskova 1963, S.4, s. 94-107.

YATSENKO, S. A., Drevnie tyurki: muzhskoj kostyum v kitajskom iskusstve 2-j pol. VI - 1-j pol. VIII vv. (Obrazy “Inyh”). Tansoxiana. Volume 14. Buenos Aires 2009, s. 3-36. 


\section{GÖKTÜRK DÖNEMİ HAREZM GÖRSEL SANATINDA TÜRK KIMLİ̆Ğ (TOK-KALE OSSUARI ÖRNEĞİNDE)}

\section{EKLER}

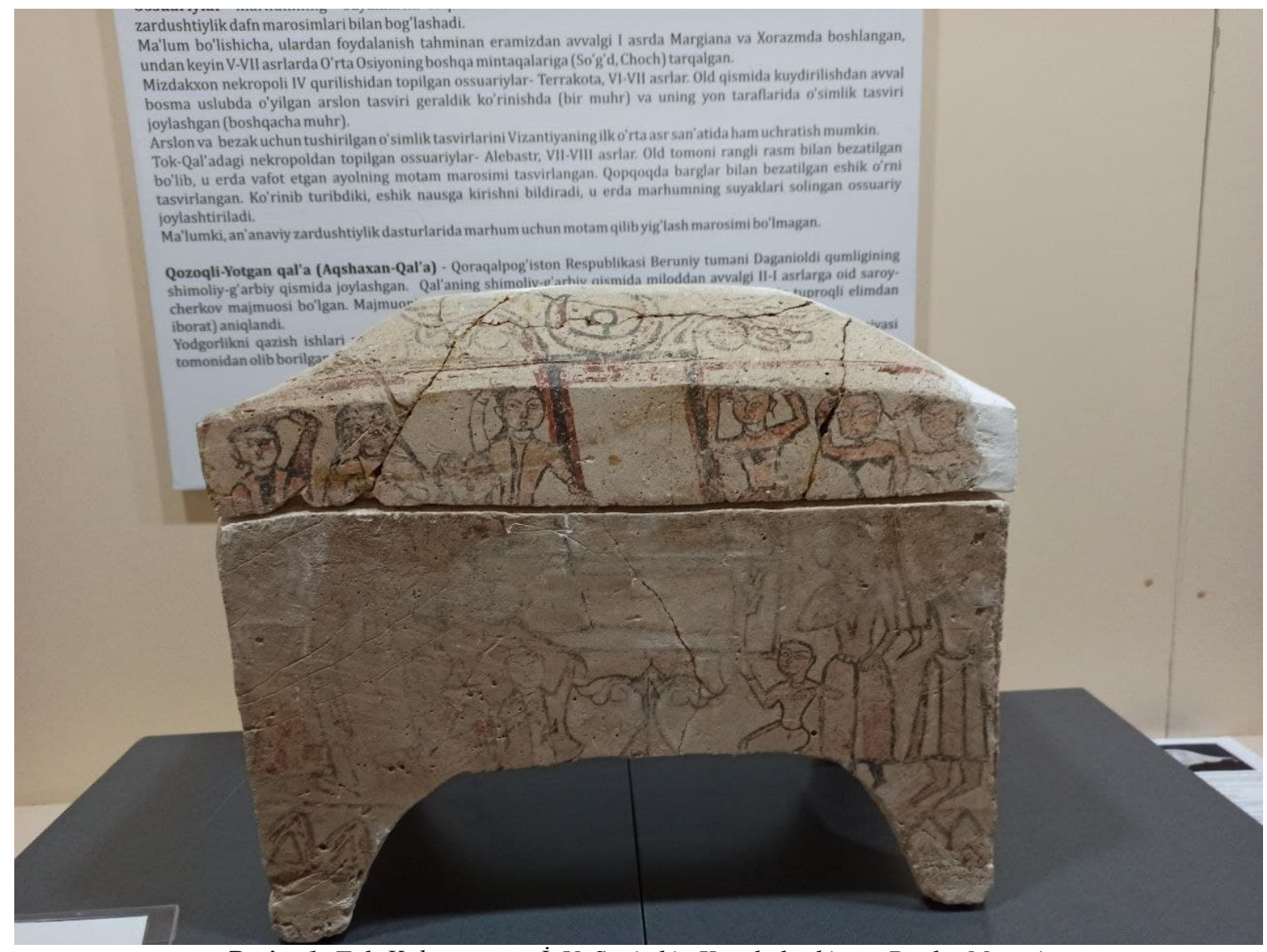

Resim 1: Tok-Kale ossuarı. İ. V. Savitskiy Karakalpakistan Devlet Müzesi. 


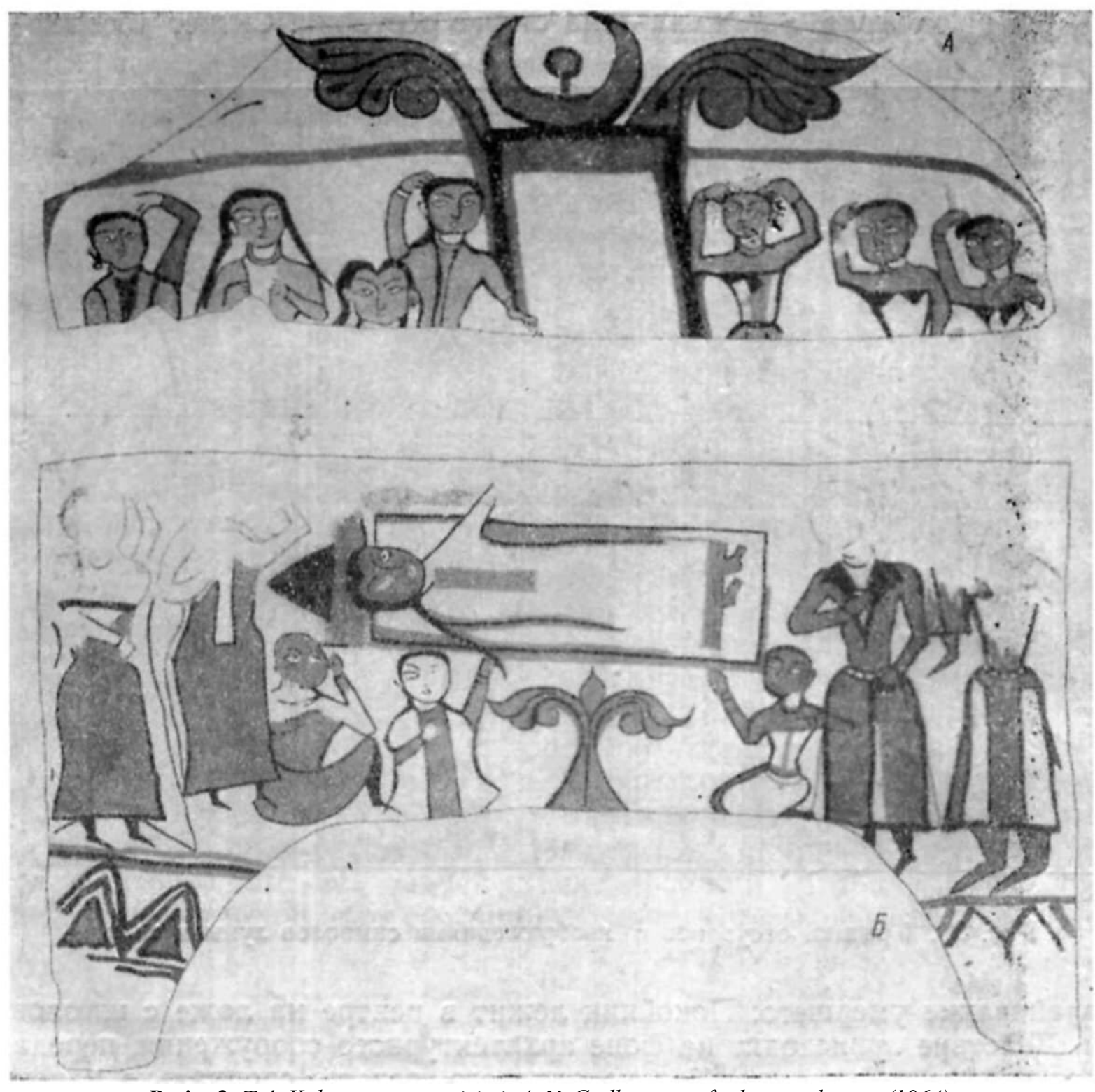

Resim 2: Tok-Kale ossuarının çizimi. A. V. Gudkova tarafindan yapılmıştır (1964). 

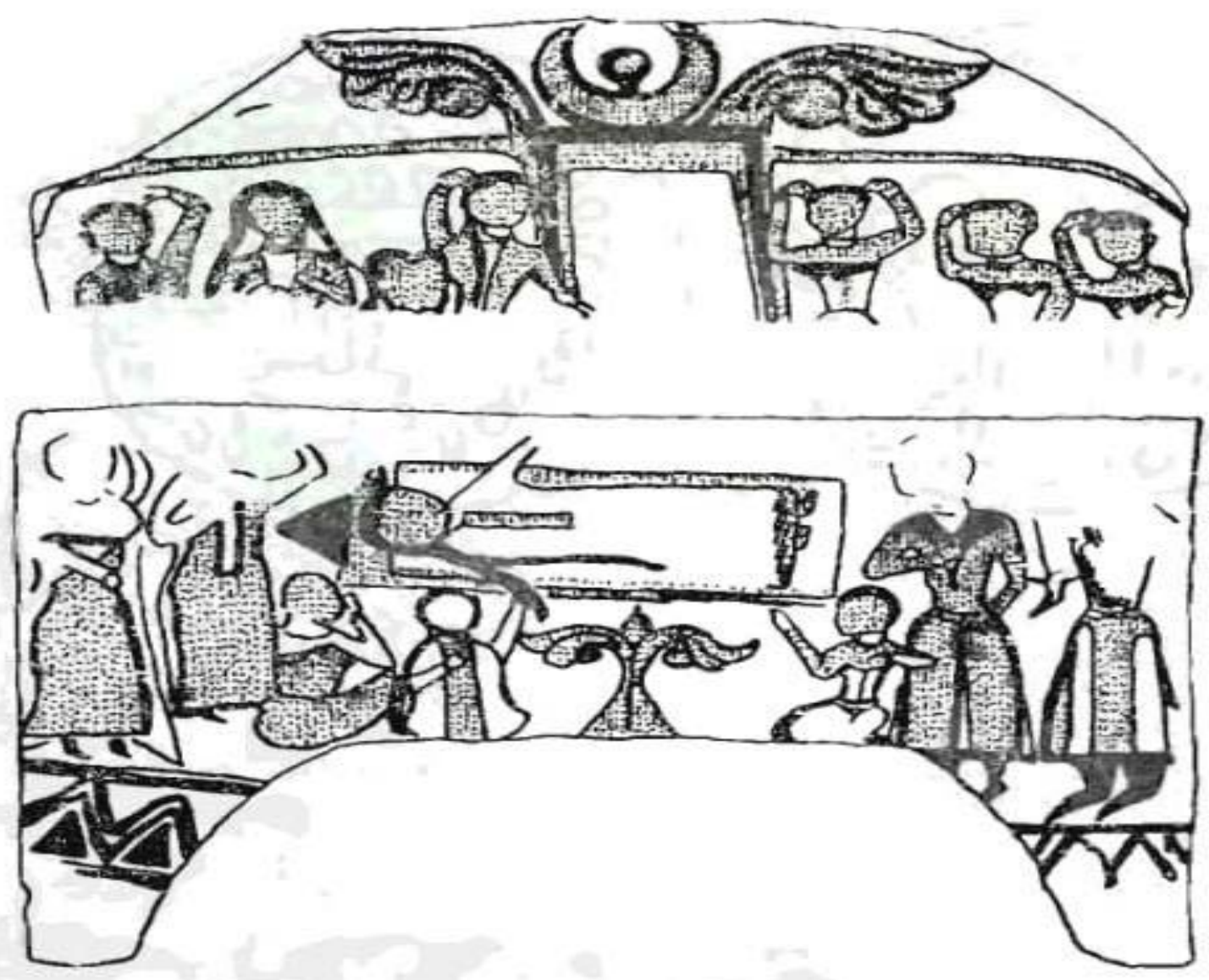

Resim 3: Tok-Kale ossuarının çizimi. Ş. M. Şükürov tarafından yapılmıştır (1977). 


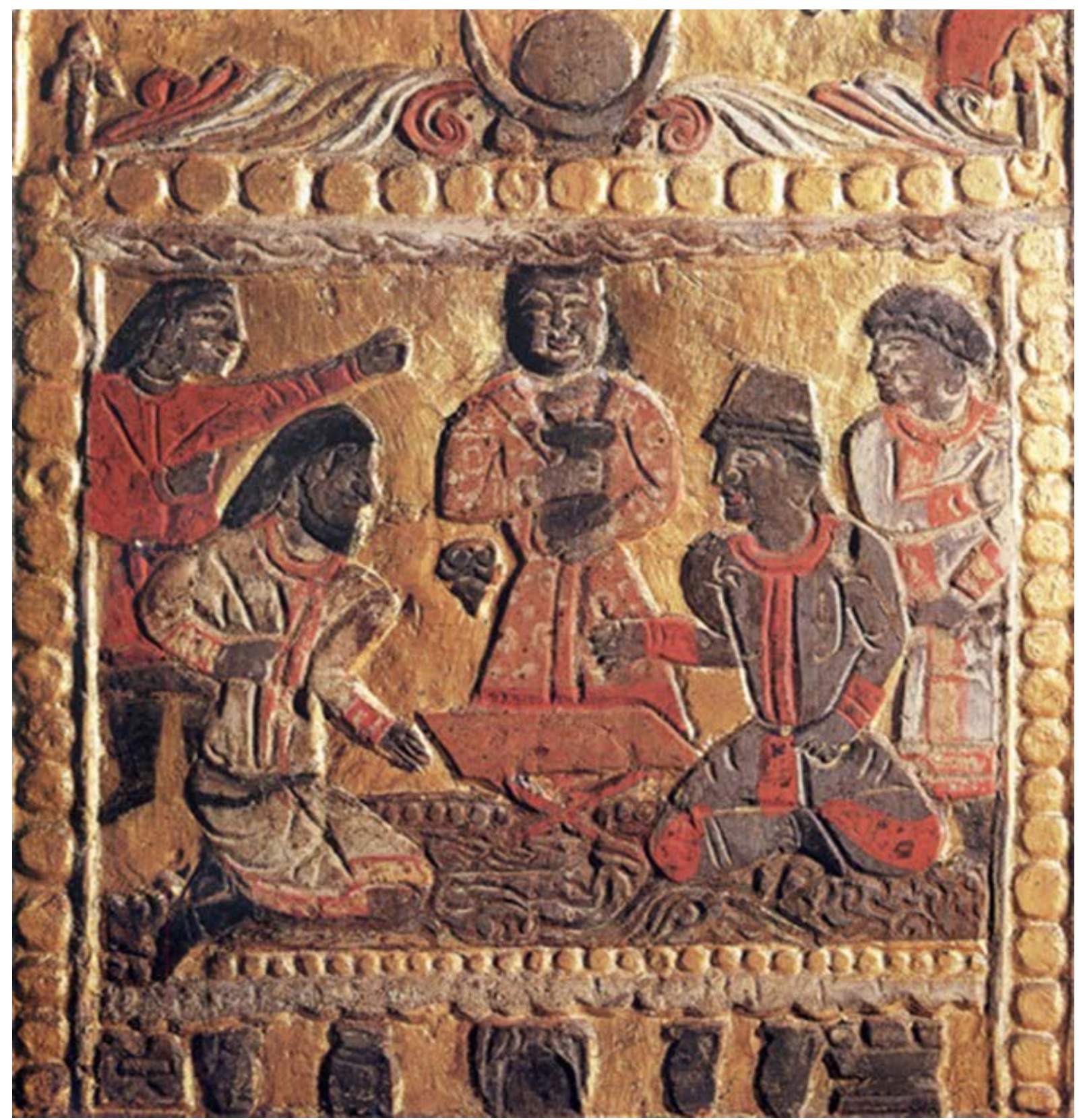

Resim 4: An Jie bir seçkin Türk ile kemik oyunu oynuyor (Anjie [An Qie] Mezarl). (Yatsenko 2009). 


\section{GÖKTÜRK DÖNEMİ HAREZM GÖRSEL SANATINDA TÜRK KIMLİ̆̇̇ \\ (TOK-KALE OSSUARI ÖRNEĞİNDE)}

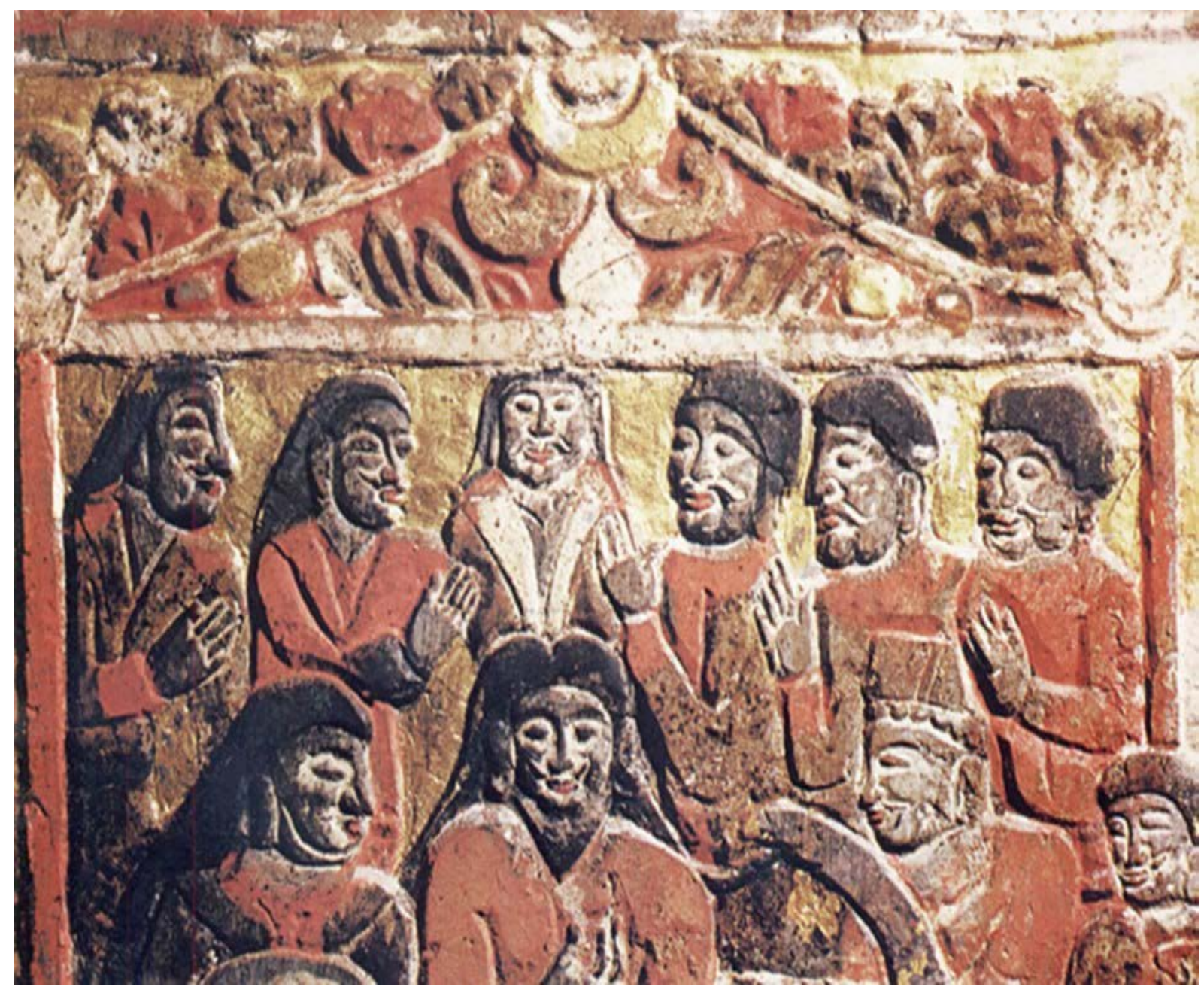

Resim 5: An Jie bir seçkin Türkü kabul ediyor (Anjie [An Qie] Mezarı). (Yatsenko 2009). 


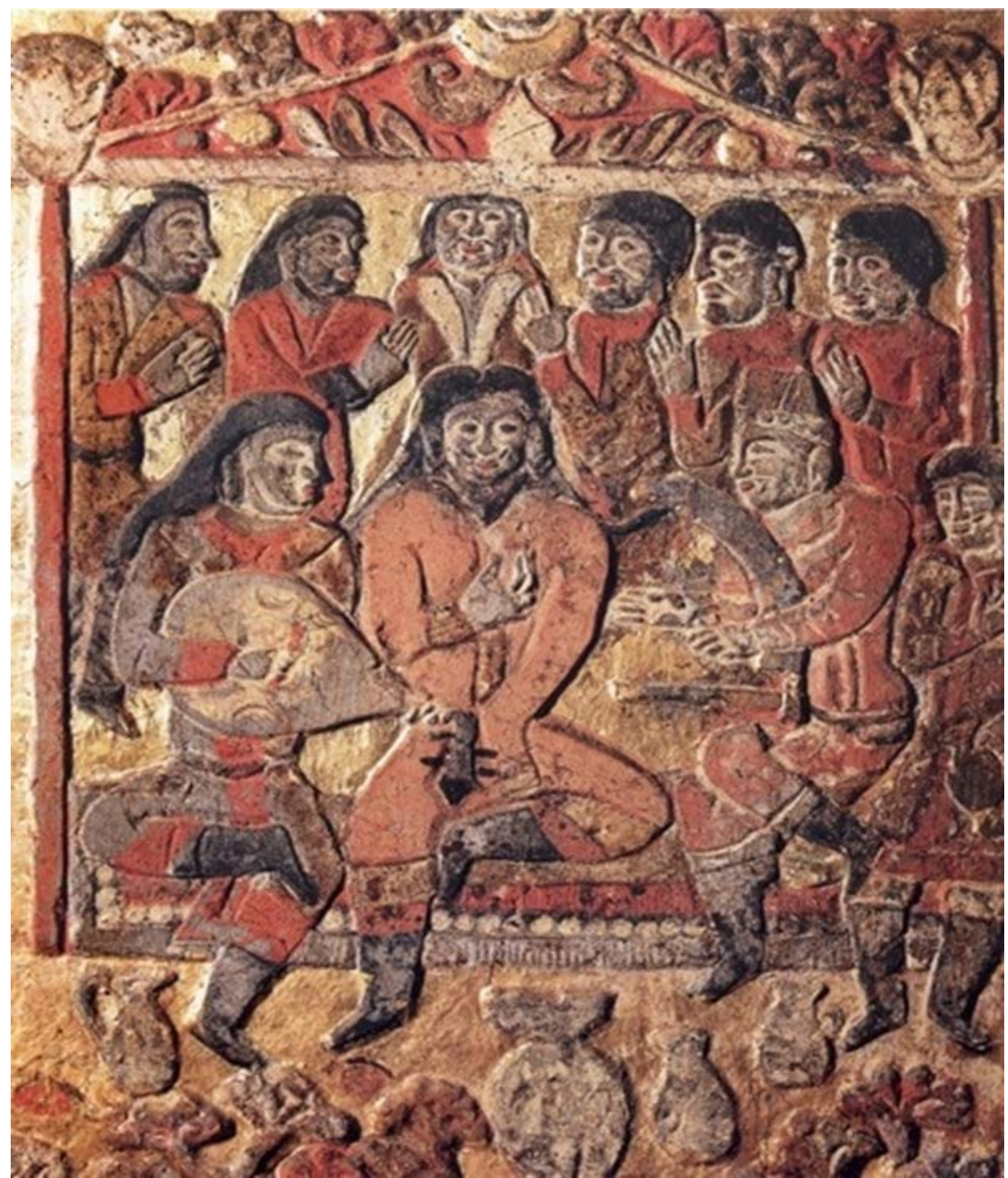

Resim 6: An Jie kendi konutunda bir seçkin Türkü kabul ediyor (Anjie [An Qie] Mezarl). (Yatsenko 2009). 


\section{GÖKTÜRK DÖNEMİ HAREZM GÖRSEL SANATINDA TÜRK KIMLIĞĠ \\ (TOK-KALE OSSUARI ÖRNEĞINDE)}
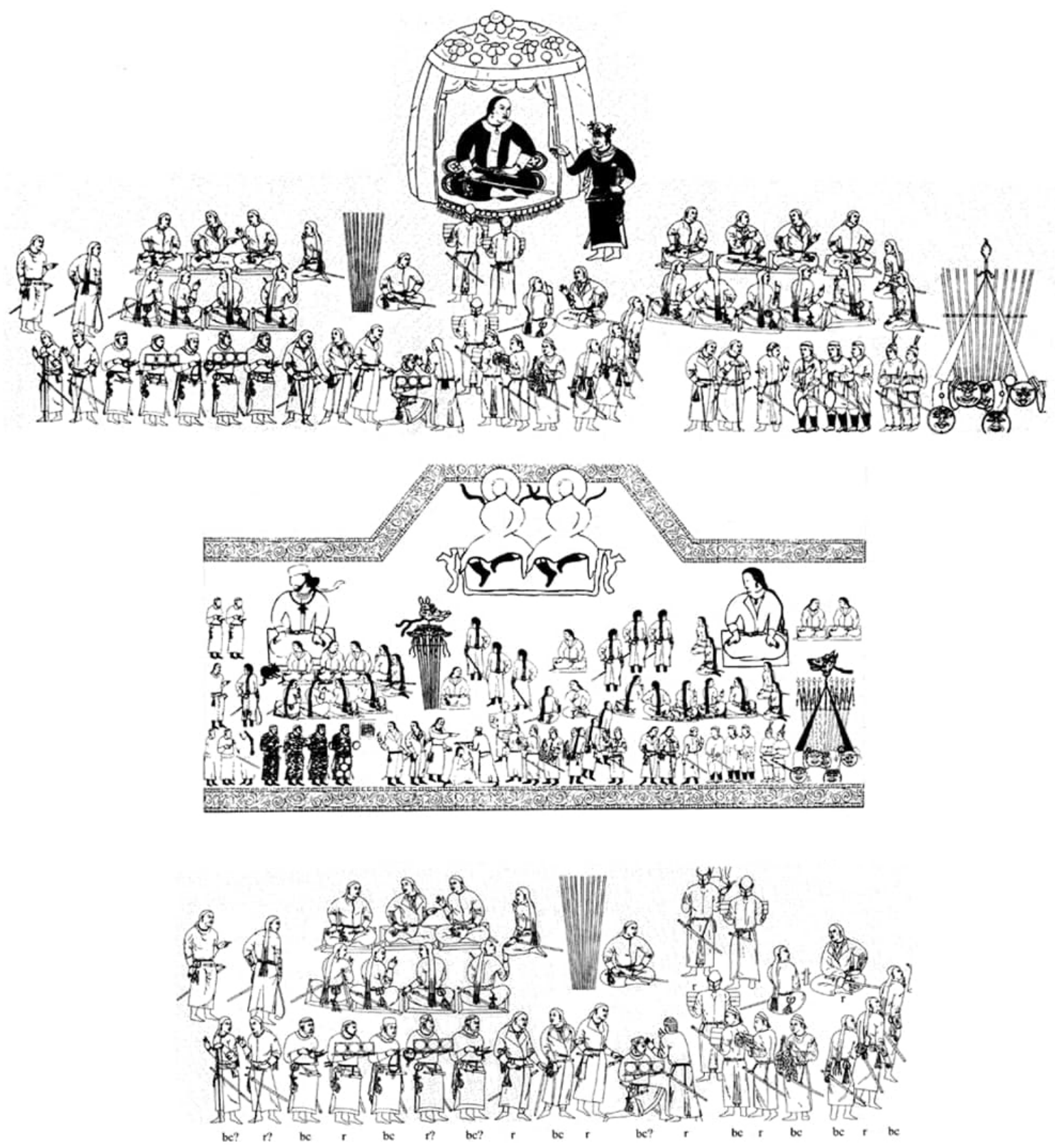

Resim 7: Türkleri içeren sahnelerin rekonstrüksiyonu, Efrasiyab (Semerkant) “Elçiler Salonu”, Batı duvarı. 7. Yüzyıl ortası: 1. (yukarıda) Ettienne de la Vaisierre versiyonu (2006); 2. (aşağıda) Marcus Mode versiyonu (2006); 3. Alt kısmının çizimi (Barbet 2006; (Yatsenko 2009). 

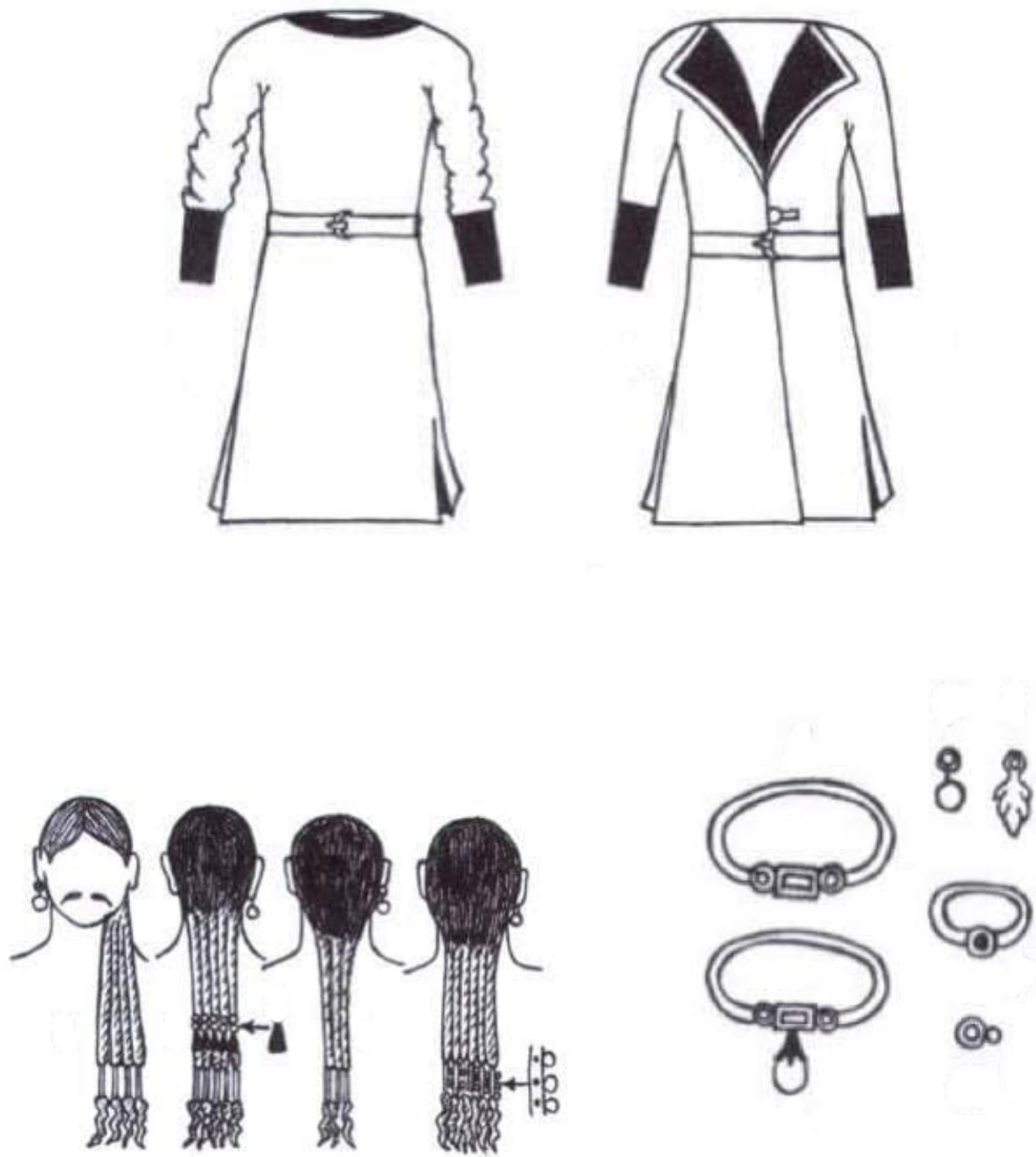

(2)

Resim 8: Efrasiyab (Semerkant) “Elçiler Salonu” duvar resimlerinde Türk giysileri. 7. Yüzyıl ortası. V. A. Yatsenko tarafindan yapılmıştır (2004). 


\section{GÖKTÜRK DÖNEMİ HAREZM GÖRSEL SANATINDA TÜRK KIMLİ̆Ğ (TOK-KALE OSSUARI ÖRNEĞINDE)}

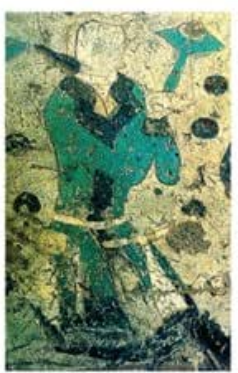

1

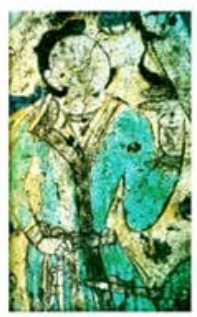

2
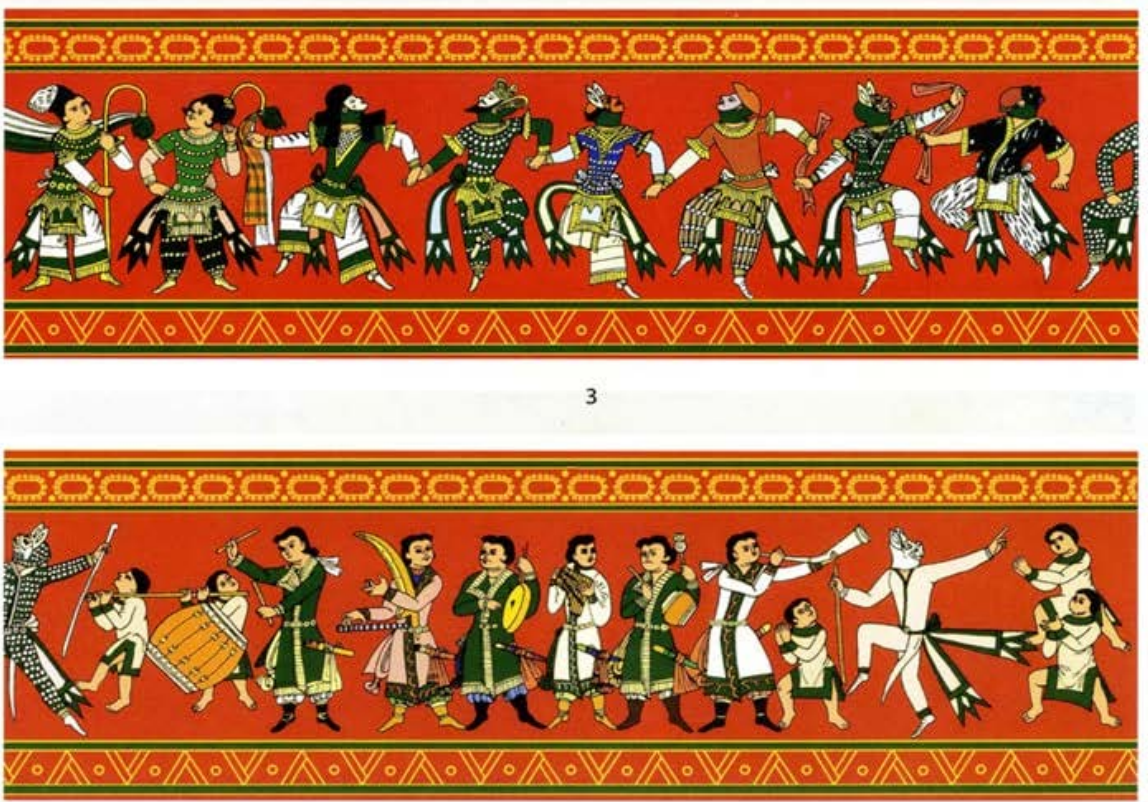

Resim 9: Erkek giysileri Kuça Vahası duvar resimlerinde. 7. Yüzyıl. Rekonstrüksiyon (Huo Xuchu, Qi Xiaoshan 2006, ss. 94, 97, 171). (Yatsenko 2009). 


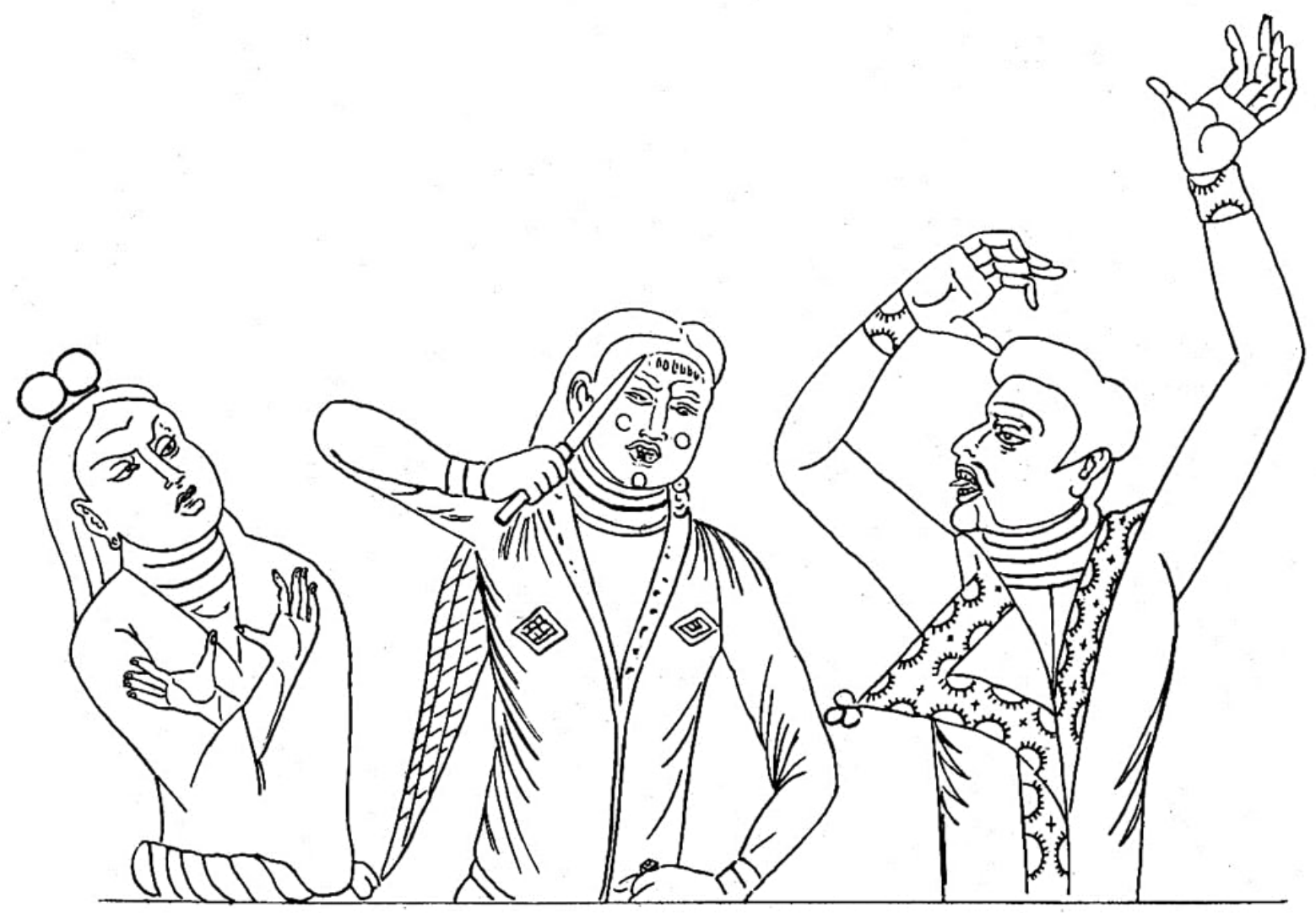

Resim 10: Yas tutan Türk. Duvar resmi detayl. “Dünya halkları Budda için yas tutmakta”. Kyzyl, Mingoi, Maya cave (Grünwedel, 1912). (Yatsenko 2009). 

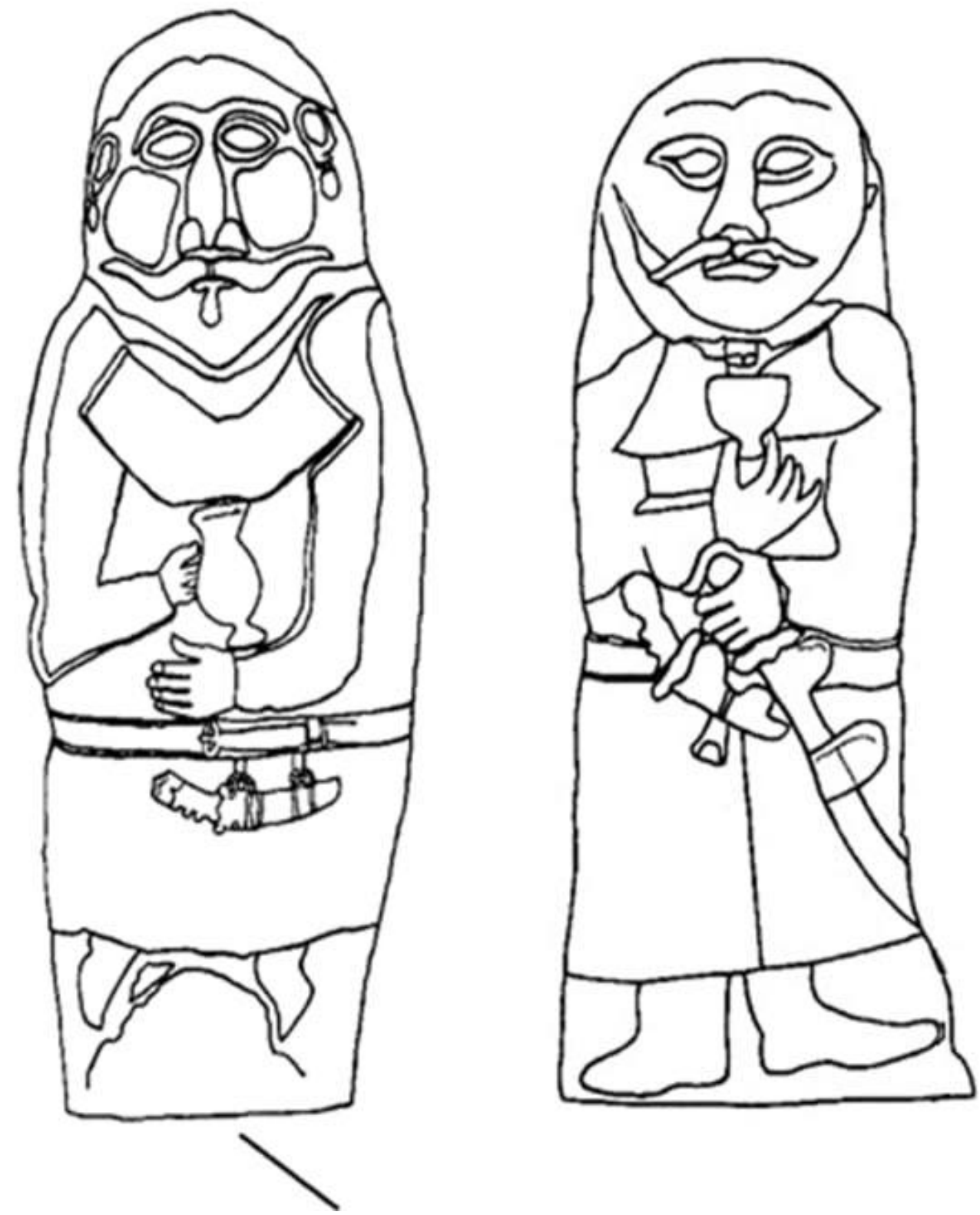

Resim 11: Balbal (taş heykeller) çizimi. G. V. Kubarev tarafından yapılmıştır (2005). 